\title{
The Democratization Potential of the Middle Class in Russia
}

Jan Švec

The paper on the case study of the contemporary regime in Russia questions the classical theory of the positive influence of middle classes on democratization processes. The author introduces arguments for the following three hypotheses. (I) An essential part of the middle class in Russia is dependent on the state, predominantly in the form of employment in the state sector. (2) This dependence is the main reason why the middle class in Russia keeps preserving the status quo. (3) The middle class in contemporary Russia, therefore, does not serve as a support for the democratic transformation of the regime. The author employs a method of statistical data analysis and concludes that the Russian middle class prefers a strong state to individual freedom and expresses deeper support for the state institutions than the lower class. The author offers the explanation based on the strong relations between the middle class and the state in Russia, supported by the data showing that public sector employees are the fastest growing segment of the Russian middle class.

Keywords: Russia, middle class, democratization, transformation.

In I959, S. M. Lipset highlighted the importance of a developed economy as a crucial factor for the spread of democracy. ${ }^{1}$ B. Moore followed with emphasizing the significance of the existence of the bourgeois ('middle class') for the establishment of democratic regimes. One of

Jan Švec. The Democratization Potential of the Middle Class in Russia. Central European Journal of International and Security Studies I3, no. 3: 12-25.

(C) 2019 CEJISS. Article is distributed under Open Access licence: Attribution NonCommercial 3.0 Unported (cc by-nc 3.0). 
his most cited quotation in the field of political science is 'no bourgeois - no democracy', which comes from his book Social Origins of Dictatorship and Democracy. ${ }^{2}$ Moore argues that bourgeois revolutions were necessary for the establishment of democracy. Robert Dahl believes that economic development leads to the formation of the middle class, which subsequently naturally supports democratic ideas and institutions. ${ }^{3}$ When economic development and the rise of the middle class occur in non-democratic regimes, Dahl evaluates it as destructive rather than beneficial for these regimes. ${ }^{4}$ In 2009, the US non-profit organization Pew Research Center issued the results of a survey which, in line with the previously mentioned works, concludes that the middle class accepts democratic values and human rights more readily than citizens with lower incomes. ${ }^{5}$

However, there are also opposing views, which challenge these modernization theories and point out that the role of the middle class is always dependent on specific political, social, and economic conditions. Based on their analysis of the situation in China, Chen and $\mathrm{Lu}$ do not believe that the Chinese middle class is a guarantee of a democratization process. Their survey shows that the middle class in China supports antiestablishment protests less (23 percent) than the lower class $\left(36\right.$ percent). ${ }^{6}$ Apart from that, fewer middle-class ( 25 percent) than lower-class (39 percent) respondents agree with the need for the competition of political parties. ${ }^{7}$ The authors state that there is a link between the individual's dependence on the state and their support of a regime change. In their survey, approximately 60 percent of middle-class respondents are employed in the state sector. ${ }^{8}$ In conclusion of their findings, the authors predict that, at least in the near future, it is highly unlikely that the Chinese middle class will serve as a catalyst for a democratic change in China. ${ }^{9}$ In accordance with these results, Gontmakher and Ross carried out an analysis of opinion polls conducted in Russia. The authors concluded that a significant part of the middle class is loyal to the regime. The reason for this might be a high number of state employees among middle-class members. ${ }^{10}$ Similarly, Rosenfeld states that the perception which considers the middle class as a motor of the democratization process in authoritarian regimes ignores the fact that in many contemporary authoritarian regimes, the middle class is the product of the regime and thrives precisely on the opportunities within state institutions and state-owned corporations. ${ }^{11}$ Steven Fish believes that the contemporary Russian authoritar- 
ian regime (Fish uses the term 'Putinism') does not wish to empower society, on the contrary it 'sustains a working class and stateservice bourgeoisie that depend on the ruler for jobs, income, and status. ${ }^{12}$

The aim of the following paper is to support with further evidence

CEIISS the theories introduced by above-mentioned authors (primarily by 3/20I9 Gontmakher, Ross and Rosenfeld) contradicting the classical modernization theory which assume that middle classes in authoritarian regimes serve as a basis for the democratization process. The author introduces arguments for the following three hypotheses: (I) An essential part of the middle class in Russia is dependent on the state, predominantly in the form of employment in the state sector; (2) This dependence is the main reason why the middle class in Russia keeps preserving the status quo; (3) The middle class in contemporary Russia therefore does not serve as a support for the democratic transformation of the regime. The author employs a method of statistical data analysis of several surveys realized in Russia during the last 8 years. Most of the analyzed data were collected by the institutions related to the Russian government: the Russian Academy of Sciences and the Russian Public Opinion Research Center. The reason for relying on these sources is the significantly limited availability of data provided by independent sources. Nevertheless, the author believes that the mentioned government-related sources are still acceptable for the purposes of this paper.

\section{Characteristics of the middle class in Russia}

Due to the different methodological approaches in defining the Russian middle class, the estimated size of the middle class varies from 3 percent to 50 percent of the Russian population. ${ }^{13}$ The Russian Academy of Sciences uses the following criteria when examining the Russian middle class: (I) level of education; (2) professional status; (3) income; and (4) selfidentification. ${ }^{14}$ In terms of the level of education, the Russian Academy of Sciences considers the middle class as those citizens who have attained at least secondary education. This condition was met by 76 percent of citizens in 20I4. The middle-class professional status includes mainly non-manual job positions, such as officials, teachers, entrepreneurs, but also soldiers (6I percent of all employees). While in Western countries we often see that the level of education and professional status might be a sufficient criterion for the characteristics of the middle class, this approach is not transferable to the case of Russia owing to inadequate financial resources in spheres such as 
education or health care. It is therefore necessary to take into account also the level of living standards. The Russian Academy of Sciences requires that the income of a middle-class member is not lower than the median in the relevant region, and at the same time, the availability of durable consumption goods is not below the median of the entire Russian population (this condition is met by 73 percent of citizens). The last criterion is selfidentification. To be included in the middle class, it is enough for the citizen to rank his or her social status with more than 4 points on a scale from I to Io. All the above-mentioned criteria are met by 42 percent of Russian citizens, who are therefore considered as middle class by the Russian Academy of Sciences. ${ }^{15}$ The Russian Academy of Sciences uses relatively mild criteria. For example, in terms of living standards, it relies only on a relative comparison with the entire Russian population. According to the Federal State Statistical Service, more than 63 percent of Russian citizens had a monthly income of less than RUB 30,000 or less than USD 500 in $2016 .{ }^{16}$ Hence, it would be probably more appropriate not to rely solely on relative criterions, but to set also an absolute minimum. Notwithstanding this fact, the present research relies significantly on this characteristic because of the wide availability of the data which are based on it.

The Russian middle class has been steadily growing since 2003, with certain fluctuations during the economic crisis. In 2003, a total of 29 percent of the population was categorized as middle-class, whereas it was already 33 percent in 20II. ${ }^{17}$ Most middle-class representatives are among younger people. Approximately 60 percent of the middle class consists of people aged between I8 and 40, while the same age group accounts only for $4 \mathrm{I}$ percent of the total Russian population. ${ }^{18}$ Middle-class representation is stronger in urban areas, although not significantly: 72 percent of middle-class citizens live in larger cities (at least district towns), compared with the 66 percent of the entire Russian population. In general, it can also be said that the further the city is from the regional center, the smaller middle-class representation it has. ${ }^{19}$ The structure of the middle class varies by region and depends on the level of social and economic development of the region. There are significant economic differences among Russian regions. For example, the national average monthly income in 2017 was RUB 31,477 (USD 5I4), but in Moscow it was RUB 61,357 (USD I,002), in the Nenets Autonomous Okrug even RUB 70,587 (USD I,152), while in the Tuva Republic, it was only RUB I3,800 (USD 225). The weakest middle class
Democratization of the Russian Middle Class 
is in the Far East Federal District, Siberian Federal District, and North Caucasus Federal District; the strongest in the Central Federal District, Volga Federal District, and Northwestern Federal District. ${ }^{20}$

\section{CEJISS The democratization potential of protests?}

3/2019 Several antiestablishment protests have taken place during the last few years in Russia, with the largest protests in $201 \mathrm{I}$ and 2012 in response to the parliamentary elections and the decision of Putin to stand again for the presidential post. Protests were perceived abroad as a democratization wave triggered by the Russian middle class. ${ }^{21}$ Even though from the "Western" point of view, it may seem that the protests in Russia were democratic, in fact, only a part of the protesters called for a democratic transformation of the regime. Overall, the protesters did not show any specific support for a democratic change. ${ }^{22}$ Chaisty and Whitefield conducted a survey of the values of protest supporters in $201 \mathrm{I}$ and 2012. ${ }^{23}$ They concluded that among those who supported antigovernment protests, there was a larger representation of people who held authoritarian and nationalist values rather than of those with democratic values. The results are similar also the other way around: those who considered democracy the best political system were not more likely to support the protests than others. Many protests were organized and supported by the official opposition, such as the Communist Party of RF, which does not actually threaten the current regime but only seeks changes within the current regime. ${ }^{24}$

Rosenfeld draws two conclusions regarding the Russian middle-class representatives employed in the public sector: firstly, their protest potential is weaker than among the other members of the middle class; secondly, they have a lesser tendency to promote democratic values. Rosenfeld estimates that state dependence in Russia reduces the likelihood of middle-class protests by 25 percent, even after the statistical adjustment of age, gender, and ideological opinions. Rosenfeld analyzed data from a Russian questionnaire survey on protests in Russia from 20II to 2013. Only I7 percent of public sector employees protested in September 2012, and a little less (I5 percent) in January 2013. ${ }^{25}$ Moreover, those who protested promoted a reform within the regime rather than a democratic transformation. ${ }^{26}$ Lankina and Voznaya analyzed data from protests between 2007 and 2012, and their results show that in regions with a high financial dependency on the state, protests occur less frequently and with fewer participants joining them. ${ }^{27}$ In addition, 
according to a survey by the independent organization Levada-Center, the overall protest potential in Russia has fallen sharply. Currently, it is the lowest for the entire monitoring period since 20I0. In March 20I8, only 6 percent of respondents said they would join a political protest if there was one in their place of residence. ${ }^{28}$

\section{Russian middle class and its dependence on the State}

Ross draws attention to the fact that the Russian middle class is not monolithic but, on the contrary, very diverse. In relation to the regime support, the greatest difference is between those whose incomes are dependent on the state and those who are paid from private sources. The part of the middle class which is economically dependent on the state tends to support the authoritarian regime more. ${ }^{29}$ The state prevents protests of this part of the middle class through the 'carrot and stick' method, using rewards and threats. State dependency includes not only payroll but also various other benefits, such as transport allowances, health insurance, access to networks of contacts, to information, as well as illegal enrichment, corruption, etc. These side benefits are not usually available in private sector jobs. ${ }^{30}$ According to Gontmakher and Ross, more than 50 percent of the Russian middle class works in the state sector. ${ }^{31}$ If we examine the data of the Russian Academy of Sciences on middleclass employment in the state sector versus the private sector, we will find the proof of their statement. The share of the middle class employed in the state sector is significantly greater than that of the rest of the population. More than two-thirds of the core middle class (i.e., higher education, managers or specialists, with basic IT skills) are employed in the state sector (68 percent), while it is somewhat less among the peripheral middle class (43 percent), and not even a quarter among the other population (24 percent). ${ }^{32}$

Furthermore, Gontmakher and Ross present data demonstrating that the share of state sector employees in the Russian middle class is growing rapidly. In 20II, almost 77 percent of all managers in the state sector ranked among the middle class, compared to only 33 percent in 2007; while only 39 percent of managers in the private sector were considered as the middle class in 20II, which is a share approximately 4 percent lower than in 2007. The number of civil servants in Russia has been rising steadily since $2012 .{ }^{33} \mathrm{In} 2016$, the number of civil servants dropped slightly, but this affected only low-ranking positions; in contrast, the number of senior officials (who are more likely to be 
considered middle-class) was rising - for example, the positions of department directors increased by 2I percent. ${ }^{34}$ The size of Russian bureaucracy has increased significantly in comparison with the period of the Soviet Union. According to the data presented by Chaim Shimar, CEIISS there were never more than 700,00o state employees in the whole So3/20I9 viet Union during I970s and I980s, while in 2006 the Russian state had about I.6 million employees, even though contemporary Russia has significantly fewer citizens than the Soviet Union had..$^{35}$ Moreover, in the case of Russia, not only civil servants but also employees of large corporations, typically in mining and energy companies (which are often state-owned), are financially dependent on the state. At the same time, the influence of the state on the economy has been growing in Russia, and according to some estimates, the state contributes up to 70 percent of the gross domestic product. ${ }^{36}$

The independent Russian non-profit organization Levada-Center conducted a questionnaire survey in $201 \mathrm{I}$ on the views and preferences of voters of various Russian political parties. ${ }^{37}$ Let us now compare some answers to the question as to interests of which social class, according to the respondents, are being represented by the strongest Russian political parties (United Russia; Communist Party; Liberal Democratic Party; Just Russia). Approximately onethird of the respondents believe that the ruling United Russia represents federal and regional officials; a similar number of people think that it represents security staff, including the army and the police. In both cases, it is a far greater proportion than for the other political parties. For instance, as for the Communist party or social democratic party Just Russia, only 3 percent of respondents believe that these parties represent security staff. A relatively small number of people (I6 percent) consider United Russia to represent the interests of the middle class, yet it is still the highest number when compared with the all remaining political parties. On the other hand, the respondents believe that of the four major political parties included in the survey, United Russia represents the lower class the least - the lower class comprises employees in services, assistants, laborers, poor people, and the unemployed. These data correspond to the fact that the Russian ruling regime relies to a large extent on well-to-do state employees rather than on the lower classes. Statistics from 201 about the Russian electorate show that 73 percent of the United Russia voters live in cities and 65 percent have at least secondary education. ${ }^{38}$ 


\section{The Russian middle class and its views on the authoritarian regime}

Let us now compare the results of several surveys conducted by the Russian Academy of Sciences in 20I4, which were focused on identifying the values accepted by the Russian middle class. In one survey, the respondents were asked about their preference for 'society of individual freedom' and 'society of social equality. ${ }^{39}$ Compared with the other segments of Russian population, the middle class has stronger preference for a 'society of individual freedom'. Nevertheless, this view is held by still less than half of the middle class. Most middle-class members (56 percent) prefer social equality to individual freedom. Another survey shows that the Russian middle class considers freedom more valuable than other segments of the population. Freedom is regarded as something without which 'life does not make sense' by 70 percent of the middle class $(56$ percent of the other population). Interestingly, almost a third of the middle class (30 percent of the middle class, 44 percent of the other population) believes that material security is the most important concern in life, whereas freedom is secondary. ${ }^{40}$

An overwhelming majority of the middle class prefers collective interests over individual interests. ${ }^{41}$ Nine out of ten middle-class representatives state that they partly or completely agree that the government should always prioritize the nation's interests over the individual's interests. With respect to understanding the potential of the middle class for democratic opposition, it is essential to point out that 92 percent of middle-class respondents maintain that the role of the opposition is to assist the government, not to criticize it. Apart from that, more than half of the middle class (5I percent) agrees totally or partially that some conflicts can be resolved only by the use of violence. When the respondents were asked which direction in the development of the country they consider to be desirable, most of them cited 'social justice, equal rights for all, a strong government that takes care of its citizens' (49 percent of the middle class, 56 percent of the other population). More than a third of the respondents (35 percent) wishes for Russia to regain the status of superpower, which is even more than the rest of the population (3I percent). A similar number of people want a 'return to national traditions and to moral values which are already time-tested' (34 percent of the middle class, 32 percent of the other population). ${ }^{42}$ Only one-third of the middle class wishes to focus on human rights and democracy; moreover, only one-tenth of the middle 
class wants to bring Russia closer to the Western countries and towards an integration into the European community. In another survey by the Russian Academy of Sciences, only 32 percent of the middle-class representatives agreed with the 'Western way' of Russia's development. It

CEJISS is more than the rest of the population (24 percent), but still less than 3/20I9 a third of the middle class. When compared with 2003, the number has fallen slightly ( 37 percent of the middle class for the 'Western way' in 2003). The 'Western way' of development is most often supported by young people. The strongest support is among middle-class members younger than 30 years ( 42 percent). ${ }^{43}$

The middle class appreciated the changes in some spheres during the previous presidency of Vladimir V. Putin more than the rest of the population. A total of I4 percent of the middle class contended that the economic situation had improved during the previous presidential term of V. Putin, while only 9 percent of the rest of the population held the same view. Most of the respondents stated that the situation remained unchanged ( 46 percent of the middle class, 42 percent of the other population). ${ }^{44}$ Slightly fewer respondents from the middle class than from the rest of the population believed that the economic situation had worsened. In other spheres, data are only available in relation to the entire population (which includes the middle class). The middle class assessed national standards of living somewhat more favorably than the entire population, 22 percent of the middle class stated that standards of living have improved, while the same stated 18 percent of the entire population. A logical explanation for the more positive evaluation of the economic situation on the part of the middle class might be that the middleclass members are themselves in a better economic position than the entire Russian population. However, when we look at the other data of the same survey, we can see that the middle class is to some degree also more lenient than the other population in the evaluation of the level of democracy and political freedoms in Russia as well as in the assessment of Russia's international position. Only 26 percent of the middle-class representatives believed that democracy and the political freedoms of citizens had deteriorated, while 33 percent of the entire population believed the same. The same numbers are for the assessment of the international position of Russia. ${ }^{45}$ According to the statistics by Petukhov, 34 percent of the entire population believe that there is a contradiction between the ruling power and the citizens, which is a slightly higher number than that for the middle class ( 32 percent). The respondents 
were also prompted to choose from two options: first, 'the current ruling power deserves support despite all its deficits', and second, 'the current ruling power must be changed at all costs'. The results were similar for the middle class and for the total population - both groups favored the first option. The first option was chosen by 73 percent of the entire population and by 75 percent of the middle class. Thus, the middle class showed slightly more support for the current power. ${ }^{46}$

The state-owned organization Russian Public Opinion Research Center ( $\mathrm{VClOM}$ ) regularly conducts a survey of public popularity of the state institutions. Respondents indicate, inter alia, in which of the three groups based on their financial situation they would place themselves, the options being: I) good / very good, 2) average, 3) bad / very bad. From the data of the survey conducted in 2017 it is apparent that respondents who rate their financial situation better often rate the state institutions more positively. ${ }^{47}$ The level of popularity among the three groups varies considerably, in tens of percent. President V. Putin enjoys the highest support and is appreciated by the majority of the representatives of all the three groups. Those in a good / very good financial situation show almost an absolute support for Mr. Putin (93 percent) and the vast majority of those in an average financial situation support Mr. Putin (87 percent). However, 'only' two-thirds (67 percent) of those less satisfied with their financial situation express support for the current president. As to the Russian government, the difference between support of the first group of respondents (75 percent) and the third group (4I percent) is even more pronounced. Similar data are in the relation to the support for the Parliament (Duma). More than half of the first and the second groups show support for the Parliament (66 percent and 54 percent respectively), while slightly more than the one-third of the respondents from the third group $(37$ percent) declare support for the Parliament. By and large, the group of the respondents who assess their financial situation as average shows a significantly higher support for the state institutions than the last group ${ }^{48}$ For the sake of clarity, we can add that the middle class would comprise respondents from the second and partly from the first group. The data show that people with a better financial background are more likely to be in favor of the regime, and the support increases in a direct proportion with the better financial situation. According to these data, the biggest threat to the regime seems to be the group that assesses its financial situation as a bad or very bad, that is, the lower class. 


\section{Conclusion}

According to the results of data analysis, the Russian middle class prefers a strong state to individual freedom; for the members of the middle class, the interests of the individual are less important than the in-

CEJISS terests of the society. The majority of the middle class regard a strong

3/2019 government and social justice as more important than democracy and freedom. Most middle-class representatives prefer cooperation with former Soviet countries rather than with Western liberal democratic countries. The middle class perceives recent developments in the country more favorably than the rest of the Russian population. Compared to the lower class, a higher number of the middleclass representatives evaluate the Russian state institution in positive terms. These results are related to the fact that a substantial part of the middle class is dependent on the state. Dependence on the state reduces the protest potential of the middle class. The ratio of state employees is significantly higher among the middle class than among the other social layers of the population. Public sector employees belong to the fastest growing segment of the Russian middle class. The results of data analysis of several surveys confirm the arguments introduced at the beginning of this article. The middle class should not be automatically considered as a guarantee of a democratization process in authoritarian regimes. The role of the middle class is always dependent on specific conditions. Where the middle class is substantially linked to the state, it will not seek a change of the regime but will prefer to maintain the status quo. Notwithstanding these results, it can be assumed, in keeping with Rosenfeld's argument that should the state fail to provide stable and secure financial and social conditions for the members of the middle class who are dependent on it, the preferences of this part of the middle class might turn against the regime. Moreover, it should be stated that because of the limited availability of sources, this article relied heavily on the surveys conducted by the institutions related to the Russian government. Hence, the author acknowledges the fact that the reliability of the results might be disputed. For this reason, it would be desirable to conduct further research preferably with the analysis of data from various sources which are independent of the government. 
The research was realized with the support of the Internal Grant Agency (IG204027) at the Faculty of International Relations, University of Economics, Prague.

JAN ŠvEC is affiliated to the Department of Political Science, Faculty of International Relations, University of Economics, Prague and may be reached atjan3svec@gmail.com.

\section{Notes}

I Martin S. Lipset (1959), 'Some Social Requisites of Democracy: Economic Development and Political Legitimacy,' The American Political Science Review 53 (I), pp. 69-I05.

2 Barrington Moore (1993), Social Origins of Dictatorship and Democracy: Lord and Peasant in the Making of the Modern World. Beacon Press, p. 4I8.

3 Robert Dahl (2000), On Democracy, Yale University Press, p. I5I.

4 Dahl (2000), p. I52.

5 Pew Research Center (2009), "The Global Middle Class: Views on Democracy, Religion, Values, and Life Satisfaction in Emerging Nations; The Pew Global Attitudes Project, February I2, available at: <http://www. pewresearch.org/wp-content/uploads/sites/2/2009/02/Global-middleclass-FINAL.pdf> (accessed or October 20I8).

6 Jie Chen and Chunlong Lu (20II), 'Democratization and the Middle Class in China: The Middle Class's Attitudes toward Democracy,' Political Research Quarterly 64 (3), p. 708.

7 Chen and $\mathrm{Lu}(2 \mathrm{OII})$, p. 7 Io.

8 Chen and $\mathrm{Lu}(2 \mathrm{OII})$, p. $7 \mathrm{I} 3$.

9 Chen and Lu (20II), p. 716.

Io Evgeny Gontmakher and Cameron Ross (2015), 'The Middle Class and Democratisation in Russia,' Europe-Asia Studies 67 (2), p. 282.

II Bryn Rosenfeld (2017), 'Reevaluating the Middle-Class Protest Paradigm: A Case-Control Study of Democratic Protest Coalitions in Russia,'American Political Science Review III (4), p. 637.

I2 Steven M. Fish (20I7), "What is Putinism?" Journal of Democracy 28 (4), p. 68

I3 Svetlana V. Mareeva (20I4a), 'Chislennost' i sostav srednego klassa v sovremennoj Rossii', in Russian Academy of Sciences (2014), Srednij klass $v$ sovremennoj Rossii: ro let spustja: Analiticheskij doklad, Moskva: Institut sociologii Rossijskoj akademii nauk, pp. 8, available at: <https://www.hse. $\mathrm{ru} / \mathrm{data} / 20 \mathrm{I} 6 / \mathrm{or} / 22 / \mathrm{Ir} 37785882 /$ full.pdf $>$ (accessed or October 20I8).

I4 Russian Academy of Sciences (20I4), Srednij klass $v$ sovremennoj Rossii: ro let spustja: Analiticheskij doklad, Moskva: Institut sociologii Rossijskoj akademii nauk, 222 pp., available at: <https://www.hse.ru/ data/20I6/or/22/II37785882/full.pdf > (accessed or October 2018).

I5 Mareeva (20I4a), p. Io.

I6 Federal State Statistics Service (2017), 'Srednij, mediannyj i modal'nyj uroven' denezhnyh dohodov naselenija v celom po Rossii i po sub'ektam
Democratization of the Russian Middle Class 
Rossijskoj Federacii,' available at: <http://www.gks.ru/free_doc/new_ site/population/bednost/tabl/tab-bedI-2-6.htm> (accessed or October 20I8).

I7 Cameron Ross (20I7), 'Rossijskij srednij klass: Agent demokratii ili oplot konservatizma?' Politicheskaja nauka (I), p. I66.

CEJISS I8 Mareeva(20I4a), p. I3.

3/20I9 I9 Ross (2017), p. I67.

20 Ross (2017), p. I66.

2I Andrew E. Kramer and David M. Herszenhorn (20II), 'Boosted by Putin, Russia's Middle Class Turns on Him,' The New York Times, II December, available at: <https://www.nytimes.com/20II/I2/ı2/world/europe/ huge-moscow-rally-suggests-a-shift-in-public-mood.html $>$ (accessed oI October 2018).

22 Nikolay Petrov (20I2), 'Is Russian Society Waking Up?' PONARS Eurasia Policy Memo (2I3), available at: <http://www.ponarseurasia.org/memo/ russian-society-waking $>$ (accessed or October 2018).

23 Paul Chaisty and Stephen Whitefield (2013), 'Forward to democracy or back to authoritarianism? The attitudinal bases of mass support for the Russian election protests of 20II-2012,' Post-Soviet Affairs 29 (5), pp. 387-403.

24 Rosenfeld (2017), p. 648.

25 Rosenfeld (2017), p. 643.

26 Rosenfeld (2017), p. 638.

27 Tomila Lankina and Alisa Voznaya (2015), 'New Data on Protest Trends in Russia's Regions,' Europe-Asia Studies 67 (2), p. 33I.

28 Levada-Center (2018), 'Protestnyj potencial,' I6 April, available at: <https:// www.levada.ru/20I8/04/16/protestnyj-potentsial-7/> (accessed or October 20I8).

29 Cameron Ross (20I7), 'Rossijskij srednij klass: Agent demokratii ili oplot konservatizma?' Politicheskaja nauka (I), pp. I63-I85.

30 Bryn Rosenfeld (2017), 'Reevaluating the Middle-Class Protest Paradigm: A Case-Control Study of Democratic Protest Coalitions in Russia,' American Political Science Review III (4), p. 64I.

3I Evgeny Gontmakher and Cameron Ross (2015), p. 282.

32 Russian Academy of Sciences (2014), p. 30.

33 Gontmakher and Ross (2015), p. 275.

34 Interfax (20I7), 'Sokrashhenie chisla gossluzhashhih v RF v 2016 godu kosnulos' lish' mladshego personala,' Interfax, ı April, available at: <http:// www.interfax.ru/russia/574369> (accessed or October 2018).

35 Chaim Shinar (2014), 'Is a Consolidation of Liberal Democracy in the Russia Federation a Reality?' European Review 22 (2), p. 325.

36 Analytical Center for the Government of the Russian Federation (2016), 'Gosudarstvennoe uchastie v rossijskoj jekonomike: goskompanii, zakupki, privatizacija,' Bjulleten' o razvitii konkurencii (3), available at: <http://ac.gov. $\mathrm{ru} /$ files/publication/a/8449.pdf $>$ (accessed or October 20I8).

37 Levada-Center (20I2), 'Rossijskie parlamentskie vybory: elektoral'nyj process pri avtoritarnom rezhime,' available at: <new.levada.ru/sites/ default/files/rossiyskieotchet.doc $>$ (accessed or October 20I8).

38 Levada-Center (2012), p. 25.

39 Svetlana V. Mareeva (20I4b), 'Cennosti i mirovozzrenie srednego klassa,' in Russian Academy of Sciences (2014), Srednij klass v sovremennoj Rossii: Io let spustja:Analiticheskij doklad, Moskva: Institut sociologii Rossijskoj akademii 
nauk, p.86, available at: <https://www.hse.ru/data/20I6/oI/22/II37785882/ full.pdf $>$ (accessed or October 20I8).

40 Mareeva (20I4b), p. 87.

4I Svetlana V. Mareeva (20I4c), 'Rossijskij srednij klass o zhelatel'nom vektore razvitija strany', in Russian Academy of Sciences (2014), Srednij klass $v$ sovremennoj Rossii: Io let spustja: Analiticheskij doklad, Moskva: Institut sociologii Rossijskoj akademii nauk, pp. Io8-Io9, available at: <https:// www.hse.ru/data/20I6/oI/22/II37785882/full.pdf > (accessed oi October 20I8).

42 Mareeva (20I4c), p. IoI.

43 Mareeva (20I4c), p. 99.

44 Julija P. Lezhnina (20I4), 'Gosudarstvo i srednij klass: vzaimopodderzhka i sotrudnichestvo ili vzaimnaja podozritel'nost' i nedoverie?' in Russian Academy of Sciences (2014), Srednij klass v sovremennoj Rossii: Io let spustja: Analiticheskij doklad, Moskva: Institut sociologii Rossijskoj akademii nauk, p. I77, available at: <https://www.hse.ru/data/20I6/oI/22/II37785882/full. pdf $>$ (accessed or October 2018).

45 Valerij Petukhov (20I4), 'Politicheskie i social'nye peremeny v strane i ikh vosprijatie srednim klassom,' in Russian Academy of Sciences (2014), Srednij klass v sovremennoj Rossii: Io let spustja: Analiticheskij doklad, Moskva: Institut sociologii Rossijskoj akademii nauk, p. I82, available at: <https:// www.hse.ru/data/20I6/oI/22/II37785882/full.pdf > (accessed or October 20I8).

46 Petukhov (2014), p. I84.

47 Russian Public Opinion Research Center (2017), 'Baza rezul'tatov oprosov rossijan "Sputnik", 26 November, available at: <https://wciom.ru/database/ baza_rezultatov_sputnik> (accessed or October 20I8).

48 Russian Public Opinion Research Center (20I7). 